\title{
Самоздійснення фахівців різних професійних груп та професій
}

Анотація. В статті аналізуються результати емпіричних досліджень в яких взяли участь фахівиі 10 професій. Встановлена загальна тендениія до перевищення рівня внутрішньопрофесійного самоздійснення над зовнішньопрофесійним. Найбільш вираженою вона є у програмістів та системних адміністраторів, лікарів, вихователів дитячих садків та вчителів середніх шкіл; найменш вираженою - у топ-менеджерів комериійних організацій.

Найвищий загальний рівень професійного самоздійснення мають програмісти/системні адміністратори й топ-менеджери комериійних організацій. Далі за ичим рівнем йдуть вчителі середніх шкіл та лікарі.

Ключові слова: самоздійснення, професійне самоздійснення, професійне становлення, ознаки самоздійснення, фахівиі.

Постановка проблеми. Постійне прискорення науково-технічного прогресу та характерні для сучасного етапу розвитку світового суспільства швидкі економічні, політичні, соціальні та духовні перетворення зумовлюють посилення уваги дослідників до феномену самоздійснення, зокрема - професійного, яке є однією із найважливіших складових, а для більшості людей - й основною формою особистісного самоздійснення. Дослідження та практичні розробки в цьому напрямі мають сприяти створенню у фахівців різних професій стійких смисложиттєвих орієнтирів у мінливому світі, усвідомленню ними особистісного сенсу професійної самореалізації, окресленню чітких та змістовних шляхів професійного самоздійснення.

Вихідні передумови. Дослідниками справедливо відзначається, що тенденції розвитку світового суспільства зумовлюють істотне посилення уваги до проблеми інноваційного (перетворювального) потенціалу людини, який розглядається як по відношенню до навколишньої дійсності, так i до її самої $[1 ; 5]$. С. М. Панченко вірно наголошує, що чим глибше людина усвідомлює себе особистістю, внутрішньо вільною, самостійно мислячою, відповідальною за свої вчинки, включеною у культуру людиною, тим гостріше переживає відсутність можливості здійснити себе у житті.
I саме стиль життя, націлений на самоздійснення зумовлює розкриття людиною своїх потенційних можливостей [6].

Особистісне самоздійснення нами розуміється як свідомий саморозвиток людини, в процесі якого розкриваються ії потенційні можливості у різних життєвих сферах, результатом чого $є$ постійне досягнення особистісно та соціально значущих ефектів, формування власного «простору життя». Професійне самоздійснення - як одна iз найважливіших форм життєвого самоздійснення, що характеризується високим рівнем розкриття особистісного потенціалу фахівця у обраній професії, розвитком його здібностей, взаємопоєднанням із професією, повсякчасною затребуваністю його професійної кваліфікації, широким використанням його професійного досвіду та здобутків іншими фахівцями [2].

Професійне самоздійснення може відбуватися у двох загальних формах: 1) зовнішньопрофесійна (досягнення значущих здобутків у різних аспектах професійної діяльності); 2) внутрішньопрофесійна (професійне самовдосконалення, спрямоване на підвищення професійної компетентності та розвиток професійно-важливих якостей).

Також нами виділено 10 ознак професійного самоздійснення: 1) внутрішньопрофесійні (потреба у професійному вдо- 
сконаленні; наявність проекту власного професійного розвитку; переважаюче задоволення власними професійними досягненнями; постійна постановка нових професійних цілей; формування власного «життєво-професійного простору»; зовнішньопрофесійні (досягнення поставлених професійних цілей; визнання досягнень фахівця професійним співтовариством; використання професійного досвіду та здобутків іншими фахівцями; розкриття особистісного потенціалу і здібностей у професії; вияв високого рівня творчості у професійній діяльності) [2].

У попередніх дослідженнях, які здійснювалися за допомогою діагностичного інтернет-сайту, нами було визначено певні особливості професійного самоздійснення фахівців різних професійних груп. Зокрема, встановлено, що фахівці професій обслуговування мають істотно нижчий за представників інших професійних груп (фахівці професій типу «людина-людина», «людина-знак», «людина-техніка», творчих та робітничих професій) як загальний рівень професійного самоздійснення, так і дві його складові - рівні внутрішньопрофесійного та зовнішньопрофесійного самоздійснення. Найвищі ж показники професійного самоздійснення мають фахівці творчих професій, хоча й не істотно (не на статистично достовірному рівні) перевищуючи показники представників інших професій. Такі результати є очевидно логічними, адже професійні обов'язки, спрямовані на обслуговування інших порівняно обмежують можливості фахівця до самоздійснення у власній професії. У той час як творчі професії за своїм змістом надають для самоздійснення найвищі можливості. Саме тому, на наш погляд, фахівці цих професій у найбільшій мірі $(\mathrm{p} \leq 0,05-0,001)$ відрізняються від інших професійних груп істотно вищою вираженістю такої ознаки як «постійна постановка нових професійних цілей» [4].

Мета статті. У цій статті ми проаналізуємо спільні та відмітні особливості професійного самоздійснення фахівців різних nрофесій, засновуючись на основі аналізу як результатів досліджень, здійсненних із використанням діагностичного інтернетсайту, так і результатів традиційних («контактних») емпіричних досліджень.

\section{Виклад методики і результатів дослі- джень.}

У дослідженнях, здійсненних із використанням діагностичного інтернет-сайту (http://prof-diagnost.org) взяло участь 332 фахівців різного віку та професій. У «контактних» емпіричних дослідженнях, проведених співробітниками лабораторії вікової психофізіології Інституту психології імені Г.С. Костюка НАПН України, взяли участь 429 фахівців 10 професій. Зокрема, 30 топ-менеджерів комерційних організацій, 32 працівника профспілкових організацій, 69 лікарів різних спеціалізацій, 19 програмістів та системних адміністраторів, 78 вихователів дитячих садків, 71 доцентів та викладачів ВН3, 35 практичних психологів галузі освіти, 25 викладачів музичних шкіл, 39 вчителів середніх шкіл, 31 науковців вищої кваліфікації. Практично всі вони були проведені в м. Києві (за виключенням вихователів, які досліджувалися у м. Житомирі). У дослідженнях було використано розроблений нами опитувальник професійного самоздійснення [3] та п'ять психодіагностичних методик. Однак у цій статті ми проаналізуємо лише результати, які було отримано на основі опитувальника.

Перше, що слід відзначити, у всіх цих фахівців виявилися достовірно вищими за фахівців першої «дистанційної» вибірки всі показники професійного самоздійснення $(\mathrm{p} \leq 0,001)$ - його загальний рівень, дві складові та 10 ознак (таблиця 1). Ми вважаємо, це може бути зумовлено тим, що у дослідженнях на діагностичному Інтернет-сайті взяли участь фахівці великої кількості різноманітних професій із різних регіонів України та Росії. А у очних дослідженнях взяли участь представники 10 професій, в яких, як і передбачалося дослідниками, вияв професійного самоздійснення мав бути порівняно більш вираженим. Окрім того, підвищення результатів за показниками самоздійснення також цілком могло бути викликано й тим, що май- 
же всі ці фахівці живуть і працюють у столиці. На користь цієї думки свідчить й те, що у вихователів, мешканців м. Житомира, загальний рівень професійного самоздійснення виявився найнижчим із досліджуваних представників 10 професій.

Таблиия 1

\section{Порівняння фахівців різних професій за узагальненими показниками Опитувальника професійного самоздійснення}

\begin{tabular}{|c|c|c|c|c|c|c|c|c|c|c|c|c|c|}
\hline & \multirow{2}{*}{\multicolumn{2}{|c|}{ Показники }} & \multicolumn{11}{|c|}{ Професії } \\
\hline & & & 1 & 2 & 3 & 4 & 5 & 6 & 7 & 8 & 9 & 10 & 11 \\
\hline \multirow{2}{*}{1} & \multirow{2}{*}{$\begin{array}{l}\text { Загальний рівень професій- } \\
\text { ного самоздійснення }\end{array}$} & $\mathrm{M}$ & 74,2 & 92,1 & 83,0 & 86,2 & 93,8 & 80,0 & 82,3 & 83,2 & 82,6 & 89,4 & 82,0 \\
\hline & & $\sigma$ & 17,0 & 3,3 & 10,4 & 10,9 & 7,3 & 12,7 & 11,8 & 12,9 & 12,4 & 10,3 & 15,3 \\
\hline \multirow{2}{*}{2} & \multirow{2}{*}{$\begin{array}{l}\text { Рівень внутрішньопрофе- } \\
\text { сійного самоздійснення }\end{array}$} & $\mathrm{M}$ & 37,8 & 46,1 & 41,8 & 45,3 & 50,4 & 41,9 & 42,9 & 43,1 & 42,7 & 46,7 & 42,2 \\
\hline & & $\sigma$ & 9,3 & 2,1 & 6,0 & 6,2 & 3,9 & 6,8 & 6,5 & 6,5 & 6,7 & 5,7 & \\
\hline & \multirow{2}{*}{$\begin{array}{l}\text { Рівень зовнішньопрофесій- } \\
\text { ного самоздійснення }\end{array}$} & $\mathrm{M}$ & 36,3 & 46,0 & 41,2 & 40,9 & 43,4 & 38,1 & 39,4 & 40,1 & 39,9 & 42,7 & 39,8 \\
\hline & & $\sigma$ & 9,0 & 1,5 & 5,6 & 5,8 & 4,3 & 7,0 & 6,3 & 7,4 & 6,7 & 5,7 & 8,1 \\
\hline
\end{tabular}

Примітки: фахівці професій: 1 - всіх типів (за виключенням професій обслуговування), продіагностовані на діагностичному Інтернет-сайті $(\mathrm{n}=275) ; 2$ - топ-менеджери комерційних організацій $(\mathrm{n}=30) ; 3$ - працівники профспілкових організацій $(\mathrm{n}=32) ; 4$ - лікарі $(\mathrm{n}=69)$; 5 - програмісти та системні адміністратори $(\mathrm{n}=19) ; 6$ - вихователі дитячих садків $(\mathrm{n}=78)$; 7 - доценти та викладачі ВНЗ $(\mathrm{n}=71) ; 8$ - практичні психологи галузі освіти $(\mathrm{n}=35)$; 9 - викладачі музичних шкіл $(\mathrm{n}=25) ; 10$ - вчителі середніх шкіл $(\mathrm{n}=39) ; 11$ - науковці вищої кваліфікації $(\mathrm{n}=31)$.

Вищенаведені у таблиці результати засвідчують таку загальну тенденцію, що рівень внутрішньопрофесійного самоздійснення перевищує рівень зовнішньопрофесійного. Найбільш вираженою вона $є$ у програмістів та системних адміністраторів, лікарів, вихователі дитячих садків та вчителів середніх шкіл $(\mathrm{p} \leq 0,001)$. Найменш вираженою - у топ-менеджерів комерційних організацій.

Найвищим загальний рівень професійного самоздійснення виявився у програмістів / системних адміністраторів й топ-менеджерів комерційних організацій, істотно перевищивши показники всіх інших професій $(\mathrm{p} \leq 0,001)$. При цьому, програмісти та системні адміністратори перевищують топ-менеджерів комерційних організацій за рівнем внутрішньопрофесійного самоздійснення, а для останніх, навпаки, властивим $\epsilon$ суттєво вищий рівень зовнішньопрофесійного.
Далі за узагальненими показниками професійного самоздійснення йдуть фахівці таких двох професій як вчителі середніх шкіл та лікарі, теж маючи значно вищі їх рівні за фахівців шістьох професій, що залишилися $(\mathrm{p} \leq 0,001)$.

Фахівці цих професій мають близькі показники професійного самоздійснення i складають третю групу за рівнем його вираженості. Це - працівники профспілкових організацій, вихователі дитячих садків, доценти та викладачі ВНЗ, практичні психологи у галузі освіти, викладачі музичних шкіл, науковці вищої кваліфікації.

Але, знову ж таки нагадаємо, що представники всіх цих 10 професій мають значно вищі показники самоздійснення за фахівців «середньостатистичної» вибірки.

Далі проаналізуємо співвідношення вияву у представників різних професій ознак внутрішньопрофесійного самоздійснення (таблиця 2).

Таблиия 2

\section{Порівняння фахівців різних професій за показниками ознак внутрішньопрофесійного самоздійснення}

\begin{tabular}{|l|l|c|c|c|c|c|c|c|c|c|c|c|c|}
\hline \multirow{2}{*}{ Показники } & \multicolumn{10}{|c|}{ Професії } \\
\cline { 3 - 13 } & & 1 & 2 & 3 & 4 & 5 & 6 & 7 & 8 & 9 & 10 & 11 \\
\hline \multirow{2}{*}{1} & $\begin{array}{l}\text { Потреба у професійному } \\
\text { вдосконаленні }\end{array}$ & $\mathrm{M}$ & 7,88 & 9,90 & 8,50 & 9,68 & 10,58 & 8,88 & 9,21 & 9,54 & 9,20 & 9,85 & 9,16 \\
\cline { 2 - 12 } & $\sigma$ & 2,4 & 0,48 & 2,22 & 1,62 & 1,12 & 1,62 & 1,61 & 1,44 & 1,63 & 1,46 & 2,33 \\
\hline
\end{tabular}




\begin{tabular}{|c|c|c|c|c|c|c|c|c|c|c|c|c|c|}
\hline & \multirow{2}{*}{\multicolumn{2}{|c|}{ Показники }} & \multicolumn{11}{|c|}{ Професії } \\
\hline & & & 1 & 2 & 3 & 4 & 5 & 6 & 7 & 8 & 9 & 10 & 11 \\
\hline \multirow{2}{*}{2} & \multirow{2}{*}{$\begin{array}{l}\text { Наявність проекту власно- } \\
\text { го професійного розвитку }\end{array}$} & M & 6,93 & 8,97 & 7,19 & 9,04 & 10,11 & 7,73 & 8,52 & 8,34 & 7,76 & 8,72 & 7,90 \\
\hline & & $\sigma$ & 2,8 & 0,71 & 2,4 & 1,86 & 1,37 & 2,26 & 1,98 & 2,07 & 2,26 & 1,74 & \\
\hline \multirow[b]{2}{*}{3} & \multirow{2}{*}{$\begin{array}{l}\text { Переважаюче задоволен- } \\
\text { ня власними професійни- } \\
\text { ми досягненнями }\end{array}$} & $\mathrm{M}$ & 6,42 & 9,03 & 8,84 & 8,61 & 10,11 & 8,46 & 8,35 & 7,66 & 8,08 & 9,21 & 8,42 \\
\hline & & $\sigma$ & 3,0 & 0,55 & 1,8 & 2,08 & 1,44 & 1,95 & 2,11 & 2,10 & 1,93 & 1,57 & 1,84 \\
\hline \multirow{2}{*}{4} & \multirow{2}{*}{$\begin{array}{l}\text { Постійна постановка но- } \\
\text { вих професійних цілей }\end{array}$} & $\mathrm{M}$ & 8,92 & 8,77 & 8,19 & 9,80 & 10,05 & 8,81 & 8,75 & 9,06 & 9,36 & 9,67 & 8,29 \\
\hline & & $\sigma$ & 2,0 & 0,81 & 1,7 & 1,78 & 1,26 & 1,83 & 1,75 & 2,02 & 1,77 & 1,69 & 1,59 \\
\hline \multirow[b]{2}{*}{5} & \multirow{2}{*}{$\begin{array}{l}\text { Формування власного } \\
\text { «життєво-професійного } \\
\text { простору» }\end{array}$} & $\mathrm{M}$ & 7,70 & 9,33 & 8,81 & 8,39 & 9,58 & 7,95 & 8,07 & 8,26 & 8,32 & 9,33 & 8,42 \\
\hline & & $\sigma$ & 2,1 & 0,66 & 1,4 & 1,70 & 1,07 & 1,61 & 1,8 & 1,68 & 1,67 & 1,66 & 2,17 \\
\hline
\end{tabular}

Примітки: фахівці професій: 1 - всіх типів (за виключенням професій обслуговування), продіагностовані на діагностичному Інтернет-сайті $(\mathrm{n}=275) ; 2$ - топ-менеджери комерційних організацій $(\mathrm{n}=30) ; 3$ — працівники профспілкових організацій $(\mathrm{n}=32) ; 4$ — лікарі $(\mathrm{n}=69) ; 5$ - програмісти та системні адміністратори $(\mathrm{n}=19) ; 6$ - вихователі дитячих садків $(\mathrm{n}=78) ; 7$ - доценти та викладачі ВНЗ $(\mathrm{n}=71) ; 8$ - практичні психологи галузі освіти $(\mathrm{n}=35) ; 9$ - викладачі музичних шкіл $(\mathrm{n}=25) ; 10$ - вчителі середніх шкіл $(\mathrm{n}=39) ; 11$ - науковці вищої кваліфікації $(\mathrm{n}=31)$.

Програмісти та системні адміністратори, як свідчать отримані результати, мають найвищі показники за всіма 5 ознаками внутрішньопрофесійного самоздійснення. Серед представників інших професій, потреба у професійному вдосконаленні та переважаюче задоволення власними професійними досягненнями найбільш вираженою $є$ в топ-менеджерів комерційних організацій. Наявність проекту власного професійного розвитку, постійна постановка нових професійних цілей - у лікарів. Формування власного «життєво-професійного простору» найбільш виражене в топменеджерів комерційних організацій та вчителів середніх шкіл.

Працівники профспілкових організацій мають порівняно найменшу потребу у професійному вдосконаленні, проектуванні власного професійного розвитку та постійній постановці нових професійних цілей. Найнижче задоволення власними професійними досягненнями властиве для практичних психологів у галузі освіти.
Формування власного «життєво-професійного простору» найменш виражене в вихователів дитячих садків.

Якщо порівнювати кількісну вираженість різних ознак внутрішньопрофесійного самоздійснення за всією вибіркою досліджуваних, то найвищий прояв мають постійна постановка нових професійних цілей та потреба у професійному вдосконаленні $(\mathrm{M}=8,91$ та 8,71), достовірно перевищуючи $(\mathrm{p} \leq 0,001)$ вираженість інших ознак - формування власного «життєво-професійного простору» $(\mathrm{M}=8,12)$, наявність проекту власного професійного розвитку $(\mathrm{M}=7,78)$ та переважаюче задоволення власними професійними досягненнями $(\mathrm{M}=7,70)$. Вираженість формування власного «життєво-професійного простору» такожє єостовірно вищою за дві останні ознаки $(\mathrm{p} \leq 0,001)$.

Кількісні дані щодо співвідношення вияву у представників різних професій ознак зовнішньопрофесійного самоздійснення наведено у таблиці 3.

Таблиия 3

\section{Порівняння фахівців різних професій за показниками ознак зовнішньопрофесійного самоздійснення}

\begin{tabular}{|l|l|c|c|c|c|c|c|c|c|c|c|c|c|}
\hline \multirow{2}{*}{ Показники } & \multicolumn{10}{|c|}{ Професії } \\
\cline { 4 - 14 } & 1 & 2 & 3 & 4 & 5 & 6 & 7 & 8 & 9 & 10 & 11 \\
\hline \multirow{2}{*}{1} & $\begin{array}{l}\text { Досягнення поставлених } \\
\text { Професійних цілей }\end{array}$ & $\mathrm{M}$ & 7,47 & 8,90 & 8,31 & 8,39 & 8,95 & 7,82 & 7,90 & 7,97 & 7,88 & 8,69 & 8,16 \\
\cline { 2 - 13 } & $\sigma$ & 2,10 &, 66 & 99 & 1,42 &, 97 & 1,68 & 1,53 & 1,68 & 1,39 & 1,34 & 1,46 \\
\hline
\end{tabular}




\begin{tabular}{|c|c|c|c|c|c|c|c|c|c|c|c|c|c|}
\hline & \multirow{2}{*}{\multicolumn{2}{|c|}{ Показники }} & \multicolumn{11}{|c|}{ Професії } \\
\hline & & & 1 & 2 & 3 & 4 & 5 & 6 & 7 & 8 & 9 & 10 & 11 \\
\hline \multirow{2}{*}{2} & \multirow{2}{*}{$\begin{array}{l}\text { Визнання досягнень фахі- } \\
\text { вця професійним співтова- } \\
\text { риством }\end{array}$} & M & 7,11 & 9,03 & 8,22 & 8,14 & 9,11 & 7,41 & 7,39 & 8,11 & 7,88 & 8,82 & 8,23 \\
\hline & & $\sigma$ & 2,18 & 66 & 1,49 & 1,39 & 1,37 & 1,90 & 1,83 & 1,74 & 1,78 & 1,53 & 1,70 \\
\hline \multirow[b]{2}{*}{3} & \multirow{2}{*}{$\begin{array}{l}\text { Використання професій- } \\
\text { ного досвіду та здобутків } \\
\text { іншими фахівцями }\end{array}$} & $\mathrm{M}$ & 7,07 & 8,97 & 8,59 & 8,12 & 8,47 & 6,51 & 7,76 & 7,26 & 7,04 & 7,56 & 7,26 \\
\hline & & $\sigma$ & 2,45 & ,41 & 1,75 & 1,84 & 1,21 & 2,10 & 1,89 & 2,04 & 2,07 & 2,10 & 2,54 \\
\hline \multirow{2}{*}{4} & \multirow{2}{*}{$\begin{array}{l}\text { Розкриття особистісного } \\
\text { потенціалу і здібностей } \\
\text { у професії }\end{array}$} & $\mathrm{M}$ & 8,09 & 9,53 & 8,31 & 8,52 & 8,53 & 8,29 & 8,34 & 8,74 & 8,64 & 9,08 & 8,74 \\
\hline & & $\sigma$ & 2,21 & 62 & 1,65 & 1,78 & 1,38 & 1,66 & 1,78 & 1,94 & 1,86 & 1,57 & 1,89 \\
\hline \multirow[b]{2}{*}{5} & \multirow{2}{*}{$\begin{array}{l}\text { Вияв високого рівня твор- } \\
\text { чості у професійній діяль- } \\
\text { ності }\end{array}$} & $\mathrm{M}$ & 6,58 & 9,67 & 7,78 & 7,64 & 8,32 & 7,94 & 7,96 & 8,03 & 8,68 & 8,62 & 7,39 \\
\hline & & $\sigma$ & 2,53 & ,47 & 2,32 & 1,64 & 1,37 & 1,64 & 1,54 & 1,75 & 1,60 & 1,20 & 2,44 \\
\hline
\end{tabular}

Примітки: фахівці професій: 1 - всіх типів (за виключенням професій обслуговування), продіагностовані на діагностичному Інтернет-сайті $(\mathrm{n}=275) ; 2$ - топ-менеджери комерційних організацій $(\mathrm{n}=30) ; 3$ — працівники профспілкових організацій $(\mathrm{n}=32) ; 4$ - лікарі $(\mathrm{n}=69) ; 5$ - програмісти та системні адміністратори $(\mathrm{n}=19) ; 6$ - вихователі дитячих садків $(\mathrm{n}=78) ; 7$ - доценти та викладачі ВН3 $(\mathrm{n}=71) ; 8$ - практичні психологи галузі освіти $(\mathrm{n}=35) ; 9$ - викладачі музичних шкіл $(\mathrm{n}=25) ; 10$ - вчителі середніх шкіл $(\mathrm{n}=39) ; 11$ - науковці вищої кваліфікації $(\mathrm{n}=31)$.

На відміну від внутрішньопрофесійного самоздійснення, програмісти та системні адміністратори мають найвищі показники лише за двома із п'яти ознак зовнішньопрофесійного самоздійснення (досягнення поставлених професійних цілей та визнання досягнень фахівця професійним співтовариством), та й то лише незначно перевищивши показники топ-менеджерів комерційних організацій. Останні мають суттєво вищі показники за представників інших професій за трьома ознаками, що залишилися.

Найнижчий рівень за ознакою досягнення поставлених професійних цілей мають вихователі дитячих садків, доценти та викладачі ВНЗ, практичні психологи у галузі освіти, викладачі музичних шкіл та вчителі середніх шкіл. За ознакою визнання досягнень фахівця професійним співтовариством - вихователі дитячих садків, доценти та викладачі ВНЗ. За використанням професійного досвіду та здобутків іншими фахівцями - вихователі дитячих садків. За розкриттям особистісного потенціалу i здібностей у професії — працівники профспілкових організацій та знову вихователі дитячих садків. За виявом високого рівня творчості у професійній діяльності — науковці вищої кваліфікації, лікарі та працівники профспілкових організацій.
За кількісною вираженістю різних ознак внутрішньопрофесійного самоздійснення за всією вибіркою досліджуваних, найвищий прояв має розкриття особистісного потенціалу і здібностей у професії $(\mathrm{M}=8,30)$, суттєво перевищуючи вираженість всіх інших ознак $(\mathrm{p} \leq 0,001)$ - досягнення поставлених професійних цілей $(\mathrm{M}=7,86)$, визнання досягнень фахівця професійним співтовариством $(\mathrm{M}=7,65)$, використання професійного досвіду та здобутків іншими фахівцями $(\mathrm{M}=7,33)$ і вияв високого рівня творчості у професійній діяльності $(\mathrm{M}=7,47)$.

Висновки. У емпіричних дослідженнях, здійсненних за участю фахівців 10 професій, встановлена загальна тенденція до перевищення рівня внутрішньопрофесійного самоздійснення над зовнішньопрофесійним. Найбільш вираженою вона $є$ у програмістів та системних адміністраторів, лікарів, вихователі дитячих садків та вчителів середніх шкіл; найменш вираженою - у топ-менеджерів комерційних організацій.

Найвищим загальний рівень професійного самоздійснення виявився у програмістів/системних адміністраторів й топ-менеджерів комерційних організацій, істотно перевищивши показники всіх інших професій. При цьому, програмісти/системні 
адміністратори перевищують топ-менеджерів комерційних організацій за рівнем внутрішньопрофесійного самоздійснення, а для останніх, навпаки, властивим є суттєво вищий рівень зовнішньопрофесійного. Далі за узагальненими показниками професійного самоздійснення йдуть фахівці таких двох професій як вчителі середніх шкіл та лікарі, теж маючи значно вищі їх рівні за фахівців інших шістьох професій.

Програмісти/системні адміністратори, як свідчать отримані результати, мають найвищі показники за всіма 5 ознаками внутрішньопрофесійного самоздійснення. Серед представників інших професій, потреба у професійному вдосконаленні та переважаюче задоволення власними професійними досягненнями найбільш вираженою $є$ в топ-менеджерів комерційних організацій. Наявність проекту власного професійного розвитку, постійна постановка нових професійних цілей - у лікарів. Формування власного «життєво-професійного простору» найбільш виражене в топменеджерів комерційних організацій та вчителів середніх шкіл.

Працівники профспілкових організацій мають порівняно найменшу потребу у професійному вдосконаленні, проектуванні власного професійного розвитку та постійній постановці нових професійних цілей. Найнижче задоволення власними професійними досягненнями властиве для практичних психологів у галузі освіти. Формування власного «життєво-професій- ного простору» найменш виражене в вихователів дитячих садків.

На відміну від внутрішньопрофесійного самоздійснення, програмісти/системні адміністратори мають найвищі показники лише за двома із п'яти ознак зовнішньопрофесійного самоздійснення (досягнення поставлених професійних цілей та визнання досягнень фахівця професійним співтовариством), та й то лише незначно перевищивши показники топ-менеджерів комерційних організацій. Останні мають суттєво вищі показники за представників інших професій за трьома ознаками, що залишилися.

За кількісною вираженістю ознак внутрішньопрофесійного самоздійснення найвищий прояв мають постійна постановка нових професійних цілей та потреба у професійному вдосконаленні, достовірно перевищуючи вираженість інших ознак. Вираженість формування власного «життєво-професійного простору» також $\epsilon$ достовірно вищою за дві останні ознаки. Серед ознак зовнішньопрофесійного самоздійснення найвищий прояв має розкриття особистісного потенціалу і здібностей у професії, суттєво перевищуючи вираженість всіх інших ознак

Перспективи подальших досліджень полягають у визначенні загальних чинників професійного самоздійснення та розробці системи психологічних заходів спрямованих на сприяння професійному самоздійсненню фахівців різних професій в умовах нинішніх бурхливих соціальноекономічних перетворень.

\section{Список використаних джерел:}

1. Клочко В.Е. Самоорганизация в психологических системах: проблемы становления ментального пространства личности (введение в трансспективный анализ) / В.Е. Клочко. - Томск : Томский государственный университет, 2005. — 174 с.

2. Кокун О.М. Життєве та професійне самоздійснення як предмет дослідження сучасної психології / О. М. Кокун // Практична психологія та соціальна робота. — 2013. - №9. - С. $1-5$.

3. Кокун О.М. Опитувальник професійного самоздійснення / О.М. Кокун // Практична психологія та соціальна робота. - 2014. - № 7. - С. 35-39.

4. Кокун О.М. Особливості професійного самоздійснення фахівців різного віку та професій / О.М. Кокун // Актуальні проблеми психології : збірник наукових праць Інституту психології імені Г.С. Костюка НАПН України. — 2014. - Том. V: Психофізіологія. Психологія праці. Експериментальна психологія. - Випуск 14. - С. 90-99.

5. Логинова И.О. Жизненное самоосуществление человека: системно-антропологический контекст : авторефер. дисс. ... д-ра психол. наук : 19.00.01 / И. О. Логинова. — Томск, 2010. $-41 \mathrm{c}$. 
6. Панченко С.М. Активізація самоздійснення особистості у контексті самоорганізації дорослої людини / С. М. Панченко // Науковий вісник Миколаївського державного університету імені В.О. Сухомлинського : збірник наукових праць. Серія «психологічні науки» / за ред. С. Д. Максименка, Н. О. Свдокимової. - Т. 2. - Вип. 7. - Миколаїв : МНУ імені В. О. Сухомлинського, 2011. - С. 222-226.

Аннотация. В статье анализируются результаты эмпирических исследований, в которых приняли участие специалисты 10 профессий. Установлена общая тендениия к превышению уровня внутреннепрофессионального самоосуществления над внешнепрофессиональным. Наиболее выражена она у программистов и системных администраторов, врачей, воспитатели детских садов и учителей средних школ; наименее выражена - у топ-менеджеров коммерческих организаций.

Наивысший общий уровень профессионального самоосуществления имеют программистыл/системные администраторы и топ-менеджеры коммерческих организаций. Далее по этому уровню идут учителя средних школ и врачи.

Ключевые слова: самоосуществление, профессиональное самоосуществление, профессиональное становление, признаки самоосуществления, специалисты.

Abstracts. The paper analyzes results of the empirical research; skilled people of 10 professions participated in it. A general tendency was determined that levels of internal professional self-fulfilment are higher than that of external professional self-fulfilment. This tendency most greatly expressed for programmers and system administrators, doctors, nursery and secondary school teachers; and it is less pronounced for top managers of commercial organizations.

Programmers/system administrators and top managers of commercial organizations have the highest overall level of professional self-fulfilment. High school teachers and doctors have the next level after programmer's one.

Keywords: self-fulfilment, professional self-fulfilment, professional development, attributes of selffulfilment, skilled people. 